\title{
PRODUCTIVE PERFORMANCE, SOME HEMATOLOGICAL TRAITS AND GENETIC RELATIONSHIP IN DIFFERENT LOCAL QUAIL AFFECTED BY DIETING THE RAPESEED (CANOLA) SEEDS POWDER
}

\author{
Hurea S. Abdulrazaq ${ }^{1}$;Sheren Dh. Mohammad ${ }^{2}$; Jinan N. Abdulrahman ${ }^{3} \&$ Sardar Y. \\ Sardary ${ }^{4}$ \\ ${ }^{1,2,3,4}$ Animal Resource Dept., Agriculture Engineering Sciences College, Salahaddin \\ University/Erbil, Iraq. \\ Email:Hurea.Abdulrazaq@su.edu.krd
}

\begin{abstract}
The impact of dietary supplementation with (2) levels of canola seed powdered and the effect of different local quails' lines and the influence of diet $\times$ line on the productive performance, Some hematological traits and genetic relationship, has to be investigated in this study. A total of 162 laying quail in three lines color white; black; and yellowish-brown were randomly distributed to (3) treatment groups with (3) replicates/ treatment/ line $\mathrm{T}^{0}$ : control (standard diet); $\mathrm{T}^{1}$ and $\mathrm{T}^{2}$ were standard diets supplemented with $1 \%$ and $3 \%$ canola seeds powder (CSP) respectively. The results of Genetic relationship using RAPD-PCR marker, noted that genetic similarity values range between 0.5 to 1 . The highest number of bands was 28 among all groups used. The highest percentage of Polymorphisms observed in the primer OPA-14. The highest range of the molecular weight was (200 - $1500 \mathrm{bp})$. The basal diet supplemented with $3 \%$ of (CSP) had higher final body weight. There was a significant $(\mathrm{P} \leq 0.05)$ difference between line groups, as the brown line exhibited higher values for final body weight. It can be noted that $\mathrm{T}^{2}$ (3\% CSP) the white line had a higher Feed intake. $1 \%$ and 3\% (CSP) provided best feed conversion ratio. $\mathrm{T}^{1}$ ( $1 \%$ CSP) had higher egg mass, egg weight and hen-day egg production. $\mathrm{T}^{2}$ recorded highest levels since hematocrit level influenced. Generally, can be concluded and recommended that using 1\%, 3\% (CSP) had helped improve body metabolism and satisfactorily impacts performance and health in different local quail lines.
\end{abstract}

Keywords: RAPD - PCR, hematocrit, laying quail

Received: 29/2/2020, Accepted: 25 / $4 / 2020$

\section{INTRODUCTION}

The latest and smallest domesticated poultry species is quail. In all of the world 131 species are found and 17-18 varieties of wild quail. (Hashanuzzaman, 2013). Local quails are a natural inhabitants of Iraq. A recently introduced economic species and is suited for meat and egg under intensive management due to their low servicing cost, rapid sexual maturity, higher growth exponential, higher tolerance to heat, suitability for higher density rearing, higher resistance to disease and higher production for egg than other poultry species. They have a shorter life cycle and less land requires for production. The quail farming as a complement to chicken and duck farming of tapping the growing market request for poultry products (Sultana et al., 2007). Moreover, the quail is an efficient converter of feed with each egg a female deposits an edible package of $8 \%$ of her body weight as compared to $3 \%$ in the case 
of chicken. The important price contributing factor in the table and hatching eggs are egg quality (Kocevski et al., 2011). Thus the economic success of a laying flock depends on the total number of eggs produced.

Canola crop originally derived from rapeseed varieties and it's a winter crop. Altered by the genetic selection that has markedly reduced its detrimental components, glucosinolate and erucic acid to a less than $20 \mu \mathrm{g}$ g-1 which is negligible level (Harker et al., 2015). An excellent source of monounsaturated acids and linolenic acid is canola oil. The increase omega-3 amount in eggs and tissue of broiler, so it is beneficial for human health (An, Guo, Ma, Yuan, and Liu, 2010).

The genetic relationship can be check by RAPD assay, it's fast, low-cost and simple. Method of genotype identification, analysis of population and pedigree, the studies of phylogenic and genetic mapping. Genetic variability in the $17^{\text {th }}$ generation of Japanese quail selected for high eggs and meat production by RAPD assay (Ali et al., 2002). The genetic variability evaluated in five breeders of local chicken using random amplification of polymorphic DNA (RAPD-PCR) (Abdulrazaq, and Suliaman, 2016). It has been used to detect specific markers in poultry, to estimate genetic relatedness among various poultry species, as well as for genome mapping (Levin et al., 1993; Ali and Ahmed, 2001), and the use of RAPD markers for a wide range of applications in poultry breeding. Howard and Moore, (1991) used various lines of commercial quails well-developed to enhance selection and breeding, there are needed more studies to characterize these strains genetically and to estimate the genetic variability. Therefore, in this study conducted to check the effects of dietary supplementation with two levels of ground Canola seed and the impact of different local quails' lines and the interacted influence of diet $\times$ line on the productive performance, some hematological traits and use RAPD-PCR as a tool in local quail to detecting polymorphism between lines and establishing genetic relationships among the quail lines.

\section{MATERIAL AND METHODS}

Conducted this study in the rule of following Ethics and Animal welfare committee guidelines at Animal Resource, College of Agricultural Engineering Sciences, Salahaddin University-Erbil, Iraq. 162 laying quails from three different color lines' were: white (W); black (B); and yellowish-brown (Y) at $10^{\text {th }}$ week of age Were obtained from a commercial farm (Quail Farming, Qushtapa), Erbil-Kurdistan Region of Iraq. distributed randomly to (3) treatment groups with (3), replicates/ treatment/ line. From each replicate contains six (6) quails, birds' sex ratio was 2 females :1 male. The birds reared in battery cages $(50 * 30 * 30 \mathrm{~cm})$. The quails fed for (5) weeks (including one week as adaptation period). The dietary treatments were as follows: $\mathrm{T}^{0}$ (control) = basal diet without addition (CSP), $\mathrm{T}^{1}=$ basal diet with $1 \%$ of canola seed powder inclusion and $\mathrm{T}^{2}=$ basal diet with $3 \%$ of canola seed powder inclusion. Table (1) showed the composition of the basal diet. Throughout the study Feed and freshwater were provided ad libitum. The floor feeders and nipple drinkers were used for feeding and drinking. Lighting plan 16 hours was applied by using fluorescence lights. A temperature of $\left(20-24 \mathrm{C}^{\circ}\right)$ with relative humidity between (50 and $60 \%$ ) was preserved throughout the experimental period. During the 
experiment, period recorded initial body weight (IBW) (g), final body weight (FBW) $(\mathrm{g})$, weekly and overall feed intake (FI) (g/bird/period), egg weight $(\mathrm{g})$ and produced eggs. The hen day egg production (HDEP\%), egg mass ( $\mathrm{g} / \mathrm{hen} /$ day), and feed conversion ratio (FCR) as (g feed:g egg), were calculated.

\section{Blood samples}

Blood samples were collected in anticoagulant tubes to determine some hematological traits. Blood samples were used for RAPD-PCR.. All laboratory work was done in a medical research center in Erbil / University of Hawler Medicine, by method of (Sharma et al.2000), the DNA extraction was carried out. This study used (15) RAPD Primers (GenScript USA company). (11 Primers) of them gave results to find a complementary DNA Genomic sites are Series in Table (2). The DNA samples purity were ranged 1.8 to 1.9 after the DNA quality isolated by the Nano Drop ${ }^{\circledR}$ spectrometer. Samples were diluted to $(30 \mathrm{ng} / \mu \mathrm{l})$ for use of RAPD PCR, in the Salahaddin Research Center / University of Salahaddin Erbil. The mixture (25 $\mu$ l) of polymerase chain reaction (PCR) and contained (30 ng) of genomic DNA, each primer $(10 \mu \mathrm{M})$. The program of PCR included an initial denaturation step at $\left(94 \mathrm{C}^{\circ}\right)$ for (5) minutes followed by (4) cycles with $\left(94 \mathrm{C}^{\circ}\right)$ for 60 seconds for DNA denaturation, annealing as mentioned with each primer, extension at $\left(72 \mathrm{C}^{\circ}\right)$ for 1 minutes and a final extension at $\left(72 \mathrm{C}^{\circ}\right)$ for (5) minutes were carried out. The amplified DNA fragments were separated on (2\%) agarose gels in 1x TBE buffer (Promega, USA) and stained with ethidium bromide. The amplified pattern was visualized on a UV trans illuminator and photographed.

\section{statistical analysis}

The statistical analysis was done according to a factorial experiment in Completely Randomized Design (CRD) $(3 \times 3)$ using (GLM) General Linear Models procedure of SAS software program package (SAS, 2012). Duncan's multiple range test was used to identify significant differences between means (Duncan, 1955). Data recording and statistical analysis RAPD patterns were recorded because of (1) or absence $(0)$. The similarity index between each group was calculated using the formula: similarity $=2 \mathrm{nxy} / \mathrm{nx}+\mathrm{ny}$. and used, genetic distance $=1-(2 \mathrm{nxy} / \mathrm{nx}+$ ny). The polymorphism of each primer was calculated basis on the following formula:-

polymorphism $=(\mathrm{Np} / \mathrm{Nt}) \times 100, \mathrm{NP}=\#$ polymorphic forms of random primer $\mathrm{Nt}=$ total number of sample primer domains (Bowditch et al., 1993). 
Table (1): Ingredients and analyzed composition of diet that fed to the local quails

\begin{tabular}{|c|c|c|c|}
\hline Ingredients (\%) & $\begin{array}{c}\text { Control diet } \\
\left(\mathrm{T}^{0}\right)\end{array}$ & \multicolumn{2}{|c|}{ Analyzed Feed Composition } \\
\hline Wheat & 175 & Crud protein (\%) & 22.91 \\
\hline Corn & 200 & Energy metabolism (Kcal) & 2930 \\
\hline Wheat flour & 250 & Lipid (\%) & 3.32 \\
\hline Soya bean Meal & 290 & Calcium (\%) & 3.11 \\
\hline $\begin{array}{c}\text { Protein Concentrate (Fish } \\
\text { Meal Concentrate) }\end{array}$ & 50 & Total phosphorus (\%) & 1.00 \\
\hline Di-Calcium Phosphate & 6 & Available phosphorus (\%) & 0.511 \\
\hline Methionine & 0.9 & Salt (\%) & 0.270 \\
\hline Lysine & 0.5 & Arginine (\%) & 1.21 \\
\hline Cholin Chloride & 0.5 & Lysine (\%) & 1.08 \\
\hline Salt & 0.85 & Methionine + Cystine (\%) & 0.633 \\
\hline Oil (vegetable oil) & 13 & Methionine (\%) & 0.382 \\
\hline Feed toxic & 1 & Threonine (\%) & 0.681 \\
\hline Lime stone & 10 & Tryptophan (\%) & 0.234 \\
\hline Vitamin premix & 0.5 & ---- & --- \\
\hline Antioxidants & 0.25 & ---- & --- \\
\hline Feed Sterilizes & 1 & ---- & ---- \\
\hline Anticoccidia & 0.5 & ------ & --- \\
\hline Total & 1000 & & \\
\hline
\end{tabular}

Table (2): Sequence, operon codes and GC content of random primers

\begin{tabular}{|c|c|c|}
\hline Primer Name & Sequence 5' to 3' & \%GC Content \\
\hline OPQ-01 & GGGACGATGG & $70 \%$ \\
\hline OPA-15 & TTCCGAACCC & $60 \%$ \\
\hline OPA-12 & TCGGCGATAG & $60 \%$ \\
\hline OPA-20 & GTTGCGATCC & $60 \%$ \\
\hline OPQ-15 & GGACGCTTCA & $60 \%$ \\
\hline OPA-03 & AGTCAGCCAC & $60 \%$ \\
\hline OPA-04 & AATCGGGCTG & $60 \%$ \\
\hline OPQ-12 & TCTCCGCAAC & $60 \%$ \\
\hline OPQ-10 & GGCTAACCGA & $60 \%$ \\
\hline OPA-19 & CAAACGTCGG & $60 \%$ \\
\hline OPA-14 & TCTGTGCTGG & $60 \%$ \\
\hline
\end{tabular}




\section{Genetic relationships}

\section{RESULTS AND DISCUSSION}

Data presented in Table (3) shows the highest number of bands was 28 bands among all groups used and which were created by the OPA-04 Primer, and the lowest number of bands were 6 band, which were created by OPA-12 Primer. The total number of bands 80 which created by all Primers and the total number of polymorphic were 29 bands. The highest percentage of the Polymorphisms observed in the primer OPA-14, 22.22 as compared with other primers in present study, While the lowest percentage of Polymorphisms were obtained by the primer of OPA-3 as 4.35. These findings are in agreement with the report of (Abdulrazaq, and Suliaman, 2016) who found that RAPD profiles of five local chicken populations were compared, the highest number of polymorphic bands were 23, while the lowest number of polymorphic bands were 7 . The highest percentage of the Polymorphisms 19.77, While the lowest were 9.48. At the similar study, (Singh and Sharma, 2002) used 12 primers and found 22\% Polymorphisms which sourced from high homology between genotypes. The highest range of the molecular weight was (200 - $1500 \mathrm{bp})$ is primer OPQ-1, and was least for primer OPA-12 which showed (600 - $800 \mathrm{bp}$ ).

Table (3): Total number of bands, polymorphic band, mono band, and monomorphic band, $\%$ of polymorphism and their size ranges from random primers.

\begin{tabular}{|c|c|c|c|c|c|c|}
\hline $\begin{array}{c}\text { Primer } \\
\text { number }\end{array}$ & $\begin{array}{c}\text { Total } \\
\text { number of } \\
\text { bands }\end{array}$ & $\begin{array}{c}\text { polymorphic } \\
\text { band }\end{array}$ & $\begin{array}{c}\text { Mono } \\
\text { band }\end{array}$ & $\begin{array}{c}\text { Monomorphic } \\
\text { band }\end{array}$ & $\begin{array}{c}\% \\
\text { Polymorphis } \\
\text { m }\end{array}$ & Size (bp) \\
\hline OPQ-01 & 26 & 3 & 6 & 23 & 11.54 & $200-1500$ \\
\hline OPA-15 & 16 & 2 & 3 & 14 & 12.50 & $500-1500$ \\
\hline OPA-12 & 6 & 1 & 1 & 5 & 16.67 & $600-800$ \\
\hline OPA-20 & 23 & 4 & 4 & 19 & 17.39 & $300-1500$ \\
\hline OPQ-15 & 18 & 3 & 3 & 15 & 16.67 & $400-1500$ \\
\hline OPA-03 & 23 & 1 & 6 & 22 & 4.35 & $200-900$ \\
\hline OPA-04 & 28 & 5 & 6 & 23 & 17.86 & $300-1200$ \\
\hline OPQ-12 & 11 & 2 & 3 & 9 & 18.18 & $400-800$ \\
\hline OPQ-10 & 10 & 2 & 2 & 8 & 20.00 & $400-700$ \\
\hline OPA-19 & 13 & 2 & 3 & 11 & 15.38 & $300-700$ \\
\hline OPA-14 & 18 & 4 & 2 & 14 & 22.22 & $100-800$ \\
\hline & 80 & 29 & 16 & 51 & & \\
\hline
\end{tabular}

\section{Genetic similarity}

Data presented in Table (4) shows the Genetic similarity using RAPD - PCR marker resulted in 11 primers, noted that genetic similarity values range between 0.5 to 1 . These genetic variations refers to the good genetic resources in the local quail and that information about genetic differences in the current study will be useful for breeders to improve local quail. Detecting similarity between chicken breed the RAPD markers are effective and they provide a potential tool for studying the inter- 
breed genetic similarity and the establishment of genetic relationships (Ali,et al.,2003).

Table. (4): similarity of RAPD profile generated through 11 primers on three lines local quail

\begin{tabular}{|c|c|c|c|}
\hline Lines & white $(\mathrm{W})$ & black $(\mathrm{B})$ & yellowish brown $(\mathrm{Y})$ \\
\hline white $(\mathrm{W})$ & 1 & 0.551 & 0.55 \\
\hline black $(\mathrm{B})$ & 0.551 & 1 & 0.716 \\
\hline yellowish brown $(\mathrm{Y})$ & 0.55 & 0.716 & 1 \\
\hline
\end{tabular}

\section{Initial and final body weight (g)}

Data presented in Table (5) shows the impact of dietary (CSP) supplementation on initial and final body weight $(\mathrm{g})$ of three local quail lines. Local quails fed supplemented with (3\%) of (CSP) had higher final body weights as compared with those fed the basal diet with no (CSP) containment. These results are in agreement with the report of (Veras, et al., 2019). The differences between line groups were significant $(\mathrm{P} \leq 0.05)$ as the brown line exhibited higher values for final body weights than the white and black lines. These findings, disagree with (Moraes et al. 2015) because the level of canola meal was increased, a linear decrease was observed for body weight $(\mathrm{P} \leq 0.05)$. In the other study was conducted the effect of different levels of full fat (CS) low in glucosinolate and erucic acid on the performance of quail. The experimental treatment included 5 and $10 \%$ (CS) in diet and fed to quail from (1 to 42) days of age. The mean total body weight was not significantly affected by (CS) inclusion levels (Vargas-Sánchez et al. 2019).

\section{Feed intake}

Data presented in Table (6) shows the effect of dietary (CSP) supplementation on eed intake (g/bird/day) of three local quail lines. It can be noted that $\mathrm{T}^{2}$ (3\% CSP) and the white line had a higher Feed intake than both Control and $\mathrm{T}^{1}$ groups during the overall period of experiment. However, In this study, significant line $\times$ dietary interaction occurred for $\mathrm{T}^{2} \mathrm{~W}$ in FI. Poultry have limited capability to handle fiber and better quality off grade (CS) should be used. However, the value in poultry diets is higher than other animals and can be a bargain. In general for poultry were found the seed of canola to be acceptable in feeding trials at the Guelph University (1977). When canola seed oil is added to the diet the fatty acid synthesis is reduced and the poultry has more energy for productive performance (Costa et al., 2008). However, despite of that the levels of methionine, linoleic acid and oil have increased with the canola meal inclusion in the diet, increasing quadratic egg weights are response up to the level of $(30 \%)$ of canola meal, with subsequent lowering. This fact may be associated with both glucosinolate and sinapine give a bitter taste and may be responsible for the reduction in voluntary feed intake (Mailer et al., 2008). 
Table (5): Effect of adding canola seed powder on initial and final body weight ( $\mathrm{g}$ ) in different lines of local quails (Mean $+\mathrm{SE}$ ).

\begin{tabular}{|c|c|c|c|c|c|}
\hline \multirow{9}{*}{$\begin{array}{c}\text { Initial } \\
\text { body } \\
\text { weigh } \\
\text { t }(g)\end{array}$} & \multirow{2}{*}{$\begin{array}{c}\text { Treatments } \\
\text { (T) }\end{array}$} & $\mathrm{T}^{0}=$ Control & $\mathrm{T}^{1}=+1 \% \mathrm{CSP}$ & $\mathrm{T}^{2}=+3 \% \mathrm{CSP}$ & L.S* \\
\hline & & $184.17 \mathrm{a} \pm 8.99$ & $186.61 \mathrm{a} \pm 6.74$ & $194.39 \mathrm{a} \pm 8.21$ & N.S \\
\hline & \multirow[t]{2}{*}{ Lines (L) } & $\mathrm{W}$ & $\mathrm{B}$ & $\mathrm{Y}$ & L.S* \\
\hline & & $184.39 a \pm 7.96$ & $187.17 \mathrm{a} \pm 8.35$ & $193.61 \mathrm{a} \pm 7.83$ & N.S \\
\hline & $\begin{array}{c}\text { Interaction } \\
\left(\mathrm{T}^{*} \mathrm{~L}\right)\end{array}$ & $\mathrm{T}^{0}$ & $\mathrm{~T}^{1}$ & $\mathrm{~T}^{2}$ & L.S* \\
\hline & $\mathrm{W}$ & $158.50 \mathrm{c} \pm 11.03$ & $204.83 \mathrm{ab} \pm 7.84$ & $189.83 a b c \pm 15.51$ & $*$ \\
\hline & $\mathrm{B}$ & $212.50 \mathrm{a} \pm 11.82$ & $167.83 b c \pm 12.20$ & $181.17 \mathrm{abc} \pm 14.56$ & * \\
\hline & $\mathrm{Y}$ & $181.50 \mathrm{abc} \pm 16.43$ & $187.17 \mathrm{abc} \pm 10.80$ & $212.17 \mathrm{a} \pm 11.52$ & N.S \\
\hline & L.S** & $*$ & $*$ & N.S & ------- \\
\hline \multirow{9}{*}{$\begin{array}{c}\text { Final } \\
\text { body } \\
\text { weigh } \\
\mathrm{t}(\mathrm{g})\end{array}$} & \multirow{2}{*}{$\begin{array}{c}\text { Treatments } \\
\text { (T) }\end{array}$} & $\mathrm{T}^{0}=$ Control & $\mathrm{T}^{1}=+1 \% \mathrm{CSP}$ & $\mathrm{T}^{2}=+3 \% \mathrm{CSP}$ & L.S.* \\
\hline & & $210.61 b \pm 6.45$ & $206.94 b \pm 8.85$ & $232.67 \mathrm{a} \pm 6.06$ & $*$ \\
\hline & \multirow[t]{2}{*}{ Lines (L) } & $\mathrm{W}$ & $\mathrm{B}$ & $\mathrm{Y}$ & L.S* \\
\hline & & $220.28 \mathrm{a} \pm 8.07$ & $218.33 a \pm 6.38$ & $211.61 \mathrm{a} \pm 8.44$ & N.S \\
\hline & $\begin{array}{c}\text { Interaction } \\
\left(\mathrm{T}^{*} \mathrm{~L}\right)\end{array}$ & $\mathrm{T}^{0}$ & $\mathrm{~T}^{1}$ & $\mathrm{~T}^{2}$ & L.S* \\
\hline & $\mathrm{W}$ & $207.33 a \pm 4.84$ & $217.83 a \pm 20.71$ & $235.67 \mathrm{a} \pm 11.43$ & N.S \\
\hline & $\mathrm{B}$ & $227.50 \mathrm{a} \pm 11.13$ & $202.50 \mathrm{a} \pm 10.22$ & $225.00 \mathrm{a} \pm 10.54$ & N.S \\
\hline & $\mathrm{Y}$ & $197.00 \mathrm{a} \pm 13.47$ & $200.50 \mathrm{a} \pm 15.18$ & $237.33 \mathrm{a} \pm 10.73$ & N.S \\
\hline & L.S** & N.S & N.S & N.S & ------- \\
\hline
\end{tabular}

$* a, b, c$ means in rows bearing different superscripts differ significantly at $\mathrm{P} \leq 0.05$.

** $\mathrm{a}, \mathrm{b}, \mathrm{c}$ means in column bearing different superscripts differ significantly at $\mathrm{P} \leq 0.05$.

\section{Egg production}

Hen-day egg production (\%) results affected by adding CSP in different lines of local quail are showed in Table (7). During the overall period of experiment, the results of hen-day egg production (\%) in $\mathrm{T}^{1}$ (1\% CSP) was significantly higher than both control $\left(\mathrm{T}^{0}\right)$ and $\mathrm{T}^{2}(3 \% \mathrm{CSP})$ groups; also white line had significantly higher than both black and yellowish-brown lines; as well as for the interacted groups $\mathrm{T}^{1} \mathrm{w}$ provided higher significantly Hen-day egg production $(\%)$ than $\mathrm{T}^{2} \mathrm{~B}$ groups provided lowest.

\section{Feed conversion ratio}

In different local quails lines feed conversion ratio ( $\mathrm{g}$ feed: $\mathrm{g}$ egg) are presented in Table (8). There was a significant effects $(\mathrm{P} \leq 0.05)$ was observed among the diets, in which the inclusion of $1 \%$ and $3 \%$ (CSP) provided higher feed conversion compared to the Control groups. the differences between line groups were significant $(\mathrm{P} \leq 0.05)$ as the White line exhibited higher values for feed conversion than the black and yellowish brown lines. In this study, significant line $\times$ dietary interaction occurred for feed conversion. Then $\mathrm{T}^{1} \mathrm{Y}$ provided higher feed conversion but with $\mathrm{T}^{0} \mathrm{~B}$ provided lowest. These results are differ from of found by (Moraes et al., 2017) who found that no effect $(\mathrm{P} \leq 0.05)$ on conversion with canola. from those found by (Hameed, Ahmad, and Rabbani, 2002). 
Table (6): Effect of adding canola seed powder on feed intake ( $\mathrm{g} / \mathrm{bird} / \mathrm{week}$ ) in different lines of local quails (Mean $+\mathrm{SE}$ ).

\begin{tabular}{|c|c|c|c|c|c|}
\hline \multicolumn{2}{|c|}{ Treatments } & $\mathrm{T}^{0}=$ Control & $\mathrm{T}^{1}=+1 \% \mathrm{CSP}$ & $\mathrm{T}^{2}=+3 \% \mathrm{CSP}$ & L.S.* \\
\hline \multicolumn{2}{|c|}{$1 \mathrm{st} \mathrm{Wk}$} & $24.02 \mathrm{a} \pm 0.066$ & $20.05 c \pm 0.06$ & $23.71 b \pm 0.091$ & * \\
\hline \multicolumn{2}{|l|}{ 2nd Wk } & $21.95 b \pm 0.063$ & $22.79 \mathrm{a} \pm 0.04$ & $16.13 c \pm 0.093$ & $*$ \\
\hline \multicolumn{2}{|l|}{$3 \mathrm{rd} \mathrm{Wk}$} & $25.82 \mathrm{~b} \pm 0.058$ & $25.50 \mathrm{c} \pm 0.11$ & $32.95 a \pm 0.150$ & $*$ \\
\hline \multicolumn{2}{|l|}{ 4th Wk } & $29.50 \mathrm{a} \pm 1.11$ & $25.35 \mathrm{~b} \pm 0.07$ & $29.99 a \pm 0.095$ & $*$ \\
\hline \multicolumn{2}{|l|}{ Average } & $25.32 \mathrm{a} \pm 0.29$ & $23.42 b \pm 0.039$ & $25.70 \mathrm{a} \pm 0.051$ & $*$ \\
\hline \multicolumn{2}{|l|}{ Lines } & W & $\mathrm{B}$ & $\mathrm{Y}$ & L.S.* \\
\hline \multicolumn{2}{|l|}{$1 \mathrm{st} \mathrm{Wk}$} & $22.72 a \pm 0.627$ & $22.61 \mathrm{ab} \pm 0.634$ & $22.45 b \pm 0.659$ & $*$ \\
\hline \multicolumn{2}{|l|}{ 2nd Wk } & $20.45 a \pm 1.014$ & $20.26 b \pm 1.049$ & $20.16 b \pm 1.078$ & $*$ \\
\hline \multicolumn{2}{|l|}{$3 \mathrm{rd} \mathrm{Wk}$} & $28.14 a \pm 1.236$ & $28.28 \mathrm{a} \pm 1.279$ & $27.85 b \pm 1.139$ & $*$ \\
\hline \multicolumn{2}{|l|}{$\begin{array}{l}\text { 4th Wk } \\
\text { Average Period }\end{array}$} & $28.65 a \pm 0.788$ & $27.52 \mathrm{a} \pm 1.180$ & $28.67 \mathrm{a} \pm 0.872$ & N.S \\
\hline \multicolumn{2}{|c|}{$\begin{array}{l}\text { Average Period } \\
\end{array}$} & $24.99 a \pm 0.378$ & $24.67 \mathrm{a} \pm 0.417$ & $24.78 \mathrm{a} \pm 0.371$ & N.S \\
\hline \multicolumn{2}{|c|}{$\begin{array}{l}\text { Periods } \\
\text { Interaction }(\mathrm{T} * \mathrm{~L})\end{array}$} & $\mathrm{T}^{0}$ & $\mathrm{~T}^{1}$ & $\mathrm{~T}^{2}$ & L.S.* \\
\hline \multirow[t]{3}{*}{ Average Period } & $\mathrm{W}$ & $25.75 \mathrm{a} \pm 0.045$ & $23.48 c \pm 0.042$ & $25.74 a \pm 0.060$ & $*$ \\
\hline & B & $24.74 b \pm 0.870$ & $23.493 \mathrm{c} \pm 0.051$ & $25.78 \mathrm{a} \pm 0.097$ & $*$ \\
\hline & $\mathrm{Y}$ & $25.48 \mathrm{ab} \pm 0.032$ & $23.306 c \pm 0.053$ & $25.57 \mathrm{ab} \pm 0.078$ & $*$ \\
\hline \multicolumn{2}{|l|}{ L.S** } & $*$ & N.S & N.S & \\
\hline
\end{tabular}

, b, c means in rows bearing different superscripts differ significantly at $\mathrm{P}<0.05$.

** a, b, c means in column bearing different superscripts differ significantly at $\mathrm{P}<0.05$.

\section{Egg weight and mass}

Egg weights ( $\mathrm{g}$ ) and egg mass ( $\mathrm{g} / \mathrm{hen} / \mathrm{day})$. Result shown in Table $(9,10)$. Generally, there were significant differences in egg weight among treatment $\mathrm{T}^{1}(1 \%$ CSP) higher Egg weight and egg mass compared other groups. However, The differences between line groups were significant $(\mathrm{P} \leq 0.05)$ as the White line exhibited higher values for Egg weight and egg mass than the black and yellowish-brown lines. The interacted $(T * L)$ groups as they compared to each other $\mathrm{T}^{1} \mathrm{w}$ provided higher egg weight and mass but with $\mathrm{T}^{2} \mathrm{~B}$ provided lowest egg weight and mass. Fundamentally egg weight altered mainly by the presence of methionine and linoleic acid in the feed. In the study of (Moraes et al. 2015) the levels of linoleic acid and methionine are increased with the canola meal inclusion. In addition, there was an increase in the level of oil by increasing the level of canola meal in the diets of quail, because of to keep them is energetic. The mass of eggs showed a quadratic response, increasing with 1\% CSP in the diet and decreasing afterwards. This showed a similar behavior due to the increase in linoleic acid and methionine levels in the feed, this response is related to egg weight. 


\section{Hematological}

Determination of hematological traits of local quails is necessary to evaluate the impact of diets in optimizing bird performance without compromising their health. Local quails are resistant to various diseases, easily adapt to different rearing conditions. Including Canola seed powder in poultry diets at different levels may be necessary to ensure adequate digestible amino acids (Khosravi et al., 2016). Table $(11,12)$ showed differences between groups with $0 \%$ CSP,1\% CSP and 3\% CSP within differ lines of bird $\mathrm{W}, \mathrm{B}, \mathrm{Y}$ which indicate, that $\mathrm{T}^{2}$ refer the highest level but not significantly this may be related to the influence of high metabolic energy in poultry that stimulates the bone marrow to produce more of red blood cells to provide more oxygen's due to erythrocytes number is a signal of the oxygen transfer capacity in the blood, thus it can be used as an indicator of health in birds, since its contribution in improving the body defense system against disease (Sergent et al., 2004), while $\mathrm{T}^{0}$ and $\mathrm{T}^{1}$ appear the lower level of erythrocyte compare to $\mathrm{T}^{2}$ because it production depend on nutrition condition. So it clear that canola seed dose not affect red blood cell count at these level which agree with (Mnisi and Mlambo, 2018) the hematological parameters, the diet had no significant effect on erythrocytes, hemoglobin, hematocrit, MCV, MCH and MCHC of local quails.

Table (7): Effect of adding canola seed powder on hen-day egg production (\%) in different lines of local quails (Mean $+\mathrm{SE}$ ).

\begin{tabular}{|c|c|c|c|c|c|c|}
\hline \multicolumn{3}{|c|}{$\frac{\text { Treatments }}{\text { Periods }}$} & $\mathrm{T}^{0}=$ Control & $\mathrm{T}^{1}=+1 \% \mathrm{CSP}$ & $\mathrm{T}^{2}=+3 \% \mathrm{CSP}$ & L.S.* \\
\hline \multicolumn{3}{|c|}{$1 \mathrm{st} \mathrm{Wk}$} & $28.05 c \pm 5.766$ & $36.61 b \pm 9.537$ & $57.16 \mathrm{a} \pm 3.898$ & $*$ \\
\hline \multicolumn{3}{|l|}{ 2nd Wk } & $71.00 \mathrm{a} \pm 7.381$ & $69.72 b \pm 17.543$ & $54.72 c \pm 5.225$ & $*$ \\
\hline \multicolumn{3}{|l|}{ 3rd Wk } & $73.11 \mathrm{~b} \pm 10.820$ & $94.11 \mathrm{a} \pm 7.7189$ & $67.50 \mathrm{~b} \pm 12.439$ & $*$ \\
\hline \multicolumn{3}{|l|}{ 4th Wk } & $99.27 \mathrm{a} \pm 12.484$ & $97.22 b \pm 8.841$ & $77.94 c \pm 16.808$ & $*$ \\
\hline \multicolumn{3}{|c|}{ Overall period } & $67.86 \mathrm{~b} \pm 5.0836$ & $74.41 \mathrm{a} \pm 10.398$ & $64.33 \pm 8.4623$ & $*$ \\
\hline Lines & \multicolumn{2}{|c|}{ Periods } & $\mathrm{W}$ & B & $\mathrm{Y}$ & L.S.* \\
\hline \multicolumn{3}{|l|}{1 st Wk } & $52.44 a \pm 10.622$ & $37.94 b \pm 5.655$ & $31.44 c \pm 4.652$ & $*$ \\
\hline \multicolumn{3}{|l|}{ 2nd Wk } & $99.55 \mathrm{a} \pm 11.548$ & $42.83 c \pm 5.339$ & $53.05 b \pm 4.436$ & * \\
\hline \multicolumn{3}{|l|}{ 3rd Wk } & $95.94 \mathrm{a} \pm 7.865$ & $46.44 b \pm 9.626$ & $92.33 \mathrm{a} \pm 5.973$ & $*$ \\
\hline \multicolumn{3}{|l|}{ 4th Wk } & $99.38 b \pm 11.293$ & $61.11 \mathrm{c} \pm 10.835$ & $99.94 a \pm 9.646$ & $*$ \\
\hline \multicolumn{3}{|c|}{ Overall Period } & $86.83 a \pm 7.292$ & $47.08 \mathrm{c} \pm 3.602$ & $69.19 \mathrm{~b} \pm 5.357$ & $*$ \\
\hline \multicolumn{3}{|c|}{$\begin{array}{l}\text { Periods } \\
\text { Interaction }(\mathrm{T} * \mathrm{~L})\end{array}$} & $\mathrm{T}^{0}$ & $\mathrm{~T}^{1}$ & $\mathrm{~T}^{2}$ & L.S.* \\
\hline \multirow{3}{*}{\multicolumn{2}{|c|}{\begin{tabular}{l|} 
Average \\
period
\end{tabular}}} & $\mathrm{W}$ & $84.58 b \pm 0.033$ & $98.95 \mathrm{a} \pm 4.1043$ & $69.208 \mathrm{~d} \pm 0.3004$ & $*$ \\
\hline & & B & $50.66 f \pm 0.150$ & $57.37 \mathrm{e} \pm 0.2602$ & $33.208 \mathrm{~g} \pm 0.083$ & $*$ \\
\hline & & $\mathrm{Y}$ & $75.83 c \pm 0.083$ & $54.66 \mathrm{ef} \pm 0.041$ & $90.583 b \pm 4.294$ & * \\
\hline \multicolumn{3}{|c|}{ L.S** } & $*$ & $*$ & $*$ & \\
\hline
\end{tabular}

, b, c means in rows bearing different superscripts differ significantly at $\mathrm{P} \leq 0.05$.

** a, b, c means in column bearing different superscripts differ significantly at $\mathrm{P} \leq 0.05$. 
Table (8): Effect of adding canola seed powder on feed conversion ratio (g feed: $\mathrm{g}$ egg) in different lines of local quails (Mean + SE). (*Day)

\begin{tabular}{|c|c|c|c|c|c|}
\hline \multicolumn{2}{|c|}{ Treatments } & $\mathrm{T}^{0}=$ Control & $\mathrm{T}^{1}=+1 \% \mathrm{CSP}$ & $\mathrm{T}^{2}=+3 \% \mathrm{CSP}$ & L.S.* \\
\hline \multicolumn{2}{|c|}{$1 \mathrm{st} \mathrm{Wk}$} & $2.14 \mathrm{a} \pm 0.189$ & $1.90 b \pm 0.073$ & $1.30 c \pm 0.095$ & $*$ \\
\hline \multicolumn{2}{|l|}{ 2nd Wk } & $0.86 b \pm 0.027$ & $1.52 \mathrm{a} \pm 0.139$ & $0.83 c \pm 0.054$ & $*$ \\
\hline \multicolumn{2}{|l|}{ 3rd Wk } & $0.88 c \pm 0.046$ & $1.02 \mathrm{~b} \pm 0.084$ & $1.12 \mathrm{a} \pm 0.068$ & $*$ \\
\hline \multicolumn{2}{|l|}{ 4th Wk } & $0.77 b \pm 0.032$ & $0.95 b \pm 0.082$ & $1.61 \mathrm{a} \pm 0.121$ & $*$ \\
\hline \multicolumn{2}{|c|}{ Average period } & $1.16 b \pm 0.067$ & $1.35 \mathrm{a} \pm 0.075$ & $1.22 b \pm 0.068$ & $*$ \\
\hline \multicolumn{2}{|c|}{ Lines $\quad$ Periods } & $\mathrm{W}$ & $\mathrm{B}$ & $\mathrm{Y}$ & L.S.* \\
\hline \multicolumn{2}{|c|}{$1 \mathrm{st} \mathrm{Wk}$} & $2.10 \mathrm{a} \pm 0.187$ & $1.65 b \pm 0.142$ & $1.59 c \pm 0.147$ & $*$ \\
\hline \multicolumn{2}{|l|}{ 2nd Wk } & $0.98 c \pm 0.017$ & $1.10 b \pm 0.174$ & $1.14 \mathrm{a} \pm 0.169$ & $*$ \\
\hline \multicolumn{2}{|l|}{ 3rd Wk } & $1.05 \mathrm{a} \pm 0.091$ & $0.98 b \pm 0.031$ & $0.99 b \pm 0.089$ & $*$ \\
\hline \multicolumn{2}{|l|}{ 4th Wk } & $1.03 \mathrm{a} \pm 0.148$ & $1.11 \mathrm{a} \pm 0.173$ & $1.18 \mathrm{a} \pm 0.134$ & N.S \\
\hline \multicolumn{2}{|c|}{ Average Period } & $1.29 \mathrm{a} \pm 0.064$ & $1.21 b \pm 0.074$ & $1.22 b \pm 0.078$ & $*$ \\
\hline \multicolumn{2}{|c|}{$\frac{\text { Periods }}{\text { Interaction }\left(\mathrm{T}^{*} \mathrm{~L}\right)}$} & $\mathrm{T}^{0}$ & $\mathrm{~T}^{1}$ & $\mathrm{~T}^{2}$ & L.S.* \\
\hline \multirow[t]{3}{*}{ Average period } & $\mathrm{W}$ & $1.42 b \pm 0.0033$ & $1.05 \mathrm{de} \pm 0.055$ & $1.41 \mathrm{~b} \pm 0.060$ & $*$ \\
\hline & $\mathrm{B}$ & $0.97 \mathrm{e} \pm 0.0230$ & $1.46 \mathrm{ab} \pm 0.018$ & $1.19 \mathrm{c} \pm 0.075$ & $*$ \\
\hline & $\mathrm{Y}$ & $1.09 \mathrm{~cd} \pm 0.001$ & $1.53 \mathrm{a} \pm 0.007$ & $1.04 \mathrm{de} \pm 0.057$ & $*$ \\
\hline \multicolumn{2}{|l|}{ L.S** } & $*$ & $*$ & $*$ & \\
\hline
\end{tabular}

, b, c means in rows bearing different superscripts differ significantly at $\mathrm{P} \leq 0.05$.

** a, b, c means in column bearing different superscripts differ significantly at $\mathrm{P} \leq 0.05$.

Our rating for hg (\%)and hematocrit (\%) are important to assess the immune status of the bird, so the high level of hg in T2 of white quail (W) group affected by the number of erythrocyte where increase in level of red blood cell coincides by increase in hg amount (Pantaya and Utami, 2018). While the results within group $\mathrm{T}^{1}$ black (B) and yallow (Y) lines appear the highest rates these may belong to line of the bird.

Hematocrit is the volume of blood percentage made up by red blood cells. The red blood cells are the most numerous blood cells and are critical for oxygen delivery and acid-base balance. That mean the results of hematocrit related to (RBC) count (Song et at.,2010). Because hematocrit in wild birds can decrease under the impact of different environmental stressors, whether the natural or anthropogenic, a possible stress related to capture and handling can be considered as one of the variation determinants. A healthy physiological situation maintenance in an otherwise stressful habitats request an increase in body oxygen capacity and hence a high level of Htc and $\mathrm{Hb}$. However, Htc and $\mathrm{Hb}$ can vary autonomously from each other and might be 
Table (9): Effect of adding canola seed powder on egg weight (g) in different lines of local quails (Mean $+\mathrm{SE}$ ).

\begin{tabular}{|c|c|c|c|c|c|}
\hline \multicolumn{2}{|c|}{ Treatments } & $\mathrm{T}^{0}=$ Control & $\mathrm{T}^{1}=+1 \% \mathrm{CSP}$ & $\mathrm{T}^{2}=+3 \% \mathrm{CSP}$ & L.S.* \\
\hline \multicolumn{2}{|c|}{$1 \mathrm{st} \mathrm{Wk}$} & $10.01 \mathrm{a} \pm 0.245$ & $9.73 a \pm 0.369$ & $8.28 b \pm 0.197$ & $*$ \\
\hline \multicolumn{2}{|l|}{ 2nd Wk } & $10.91 \mathrm{a} \pm 0.245$ & $10.82 \mathrm{a} \pm 0.229$ & $9.28 \mathrm{~b} \pm 0.293$ & $*$ \\
\hline \multicolumn{2}{|l|}{$3 \mathrm{rd} \mathrm{Wk}$} & $11.34 \mathrm{a} \pm 0.285$ & $11.98 \mathrm{a} \pm 0.977$ & $11.26 \mathrm{a} \pm 1.124$ & N.S \\
\hline \multicolumn{2}{|l|}{ 4th Wk } & $11.16 \mathrm{a} \pm 0.260$ & $11.39 \mathrm{a} \pm 0.202$ & $9.58 \mathrm{~b} \pm 1.103$ & $*$ \\
\hline \multicolumn{2}{|l|}{ Overall period } & $10.86 \mathrm{a} \pm 0.244$ & $10.98 a \pm 0.385$ & $9.60 \mathrm{~b} \pm 0.310$ & $*$ \\
\hline \multicolumn{2}{|l|}{ Lines } & W & $\mathrm{B}$ & $\mathrm{Y}$ & L.S.* \\
\hline \multicolumn{2}{|l|}{1 st Wk } & $9.84 a \pm 0.418$ & $9.18 \mathrm{~b} \pm 0.421$ & $9.01 \mathrm{~b} \pm 0.231$ & $*$ \\
\hline \multicolumn{2}{|l|}{ 2nd Wk } & $10.65 a \pm 0.395$ & $10.04 c \pm 0.465$ & $10.30 \mathrm{~b} \pm 0.095$ & $*$ \\
\hline \multicolumn{2}{|l|}{$3 \mathrm{rd} \mathrm{Wk}$} & $12.68 \mathrm{a} \pm 0.878$ & $10.20 \mathrm{~b} \pm 0.431$ & $11.71 \mathrm{ab} \pm 1.076$ & $*$ \\
\hline \multicolumn{2}{|l|}{ 4th Wk } & $11.90 \mathrm{a} \pm 0.165$ & $10.91 \mathrm{a} \pm 0.298$ & $9.320 \mathrm{~b} \pm 1.014$ & $*$ \\
\hline \multicolumn{2}{|c|}{$\begin{array}{l}\text { Overall Period } \\
\text { Periods }\end{array}$} & $11.27 \mathrm{a} \pm 0.350$ & $10.08 b \pm 0.406$ & $10.08 \mathrm{~b} \pm 0.217$ & $*$ \\
\hline \multicolumn{2}{|c|}{$\frac{\text { Periods }}{\text { Interaction }(\mathrm{T} * \mathrm{~L})}$} & $\mathrm{T}^{0}$ & $\mathrm{~T}^{1}$ & $\mathrm{~T}^{2}$ & L.S.* \\
\hline \multirow[t]{3}{*}{ Overall period } & $\mathrm{W}$ & $11.29 \mathrm{~b} \pm 0.073$ & $12.33 \mathrm{a} \pm 0.607$ & $10.21 c \pm 0.021$ & * \\
\hline & $\mathrm{B}$ & $11.40 \mathrm{ab} \pm 0.024$ & $10.21 c \pm 0.105$ & $8.640 \mathrm{~d} \pm 0.024$ & $*$ \\
\hline & $\mathrm{Y}$ & $9.89 \mathrm{c} \pm 0.0304$ & $10.41 b c \pm 0.206$ & $9.963 \mathrm{c} \pm 0.667$ & N.S \\
\hline \multicolumn{2}{|l|}{ L.S** } & $*$ & $*$ & $*$ & \\
\hline
\end{tabular}

, b, c means in rows bearing different superscripts differ significantly at $\mathrm{P} \leq 0.05$.

** a, b, c means in column bearing different superscripts differ significantly at $\mathrm{P} \leq 0.05$.

high or low due to several other stress related problems such as dehydration or anemia's. Which can result from conditions such as starvation, parasite infections, or hemolytic diseases (Minias, 2015).The results in Table (13) showed that $\mathrm{T}^{2}$ recorded the highest levels compared to other groups with significant differences due to the diet that contain 3\% CSP since hematocrit level influenced by nutrient and environment. The hematological constituents demonstrate a physiological response of birds to internal and external environments such as type of diet and behavioral dieting patterns (Challenge et al., 2001; Emenalom et al. 2004). 
Table (10): Effect of adding canola seed powder on egg mass (g/hen/day ) in different lines of local quails (Mean $+\mathrm{SE}$ ).

\begin{tabular}{|c|c|c|c|c|}
\hline $\begin{array}{l}\text { Treatments } \\
\text { Periods }\end{array}$ & $\mathrm{T}^{0}=$ Control & $\mathrm{T}^{1}=+1 \% \mathrm{CSP}$ & $\mathrm{T}^{2}=+3 \% \mathrm{CSP}$ & L.S.* \\
\hline $1 \mathrm{st} \mathrm{Wk}$ & $2.82 \mathrm{c} \pm 0.61$ & $3.76 \mathrm{~b} \pm 1.089$ & $4.72 \mathrm{a} \pm 0.324$ & $*$ \\
\hline 2nd Wk & $7.82 \mathrm{~b} \pm 0.912$ & $7.86 \mathrm{a} \pm 2.12$ & $5.19 \mathrm{c} \pm 0.631$ & $*$ \\
\hline 3rd Wk & $8.25 \mathrm{~b} \pm 1.23$ & $11.31 \mathrm{a} \pm 1.308$ & $7.99 \mathrm{c} \pm 1.40$ & $*$ \\
\hline 4th Wk & $10.08 \mathrm{a} \pm 1.05$ & $11.04 a \pm 1.20$ & $6.65 \mathrm{~b} \pm 1.23$ & $*$ \\
\hline Overall period & $7.24 \mathrm{~b} \pm 0.56$ & $8.49 \mathrm{a} \pm 1.41$ & $6.14 c \pm 0.89$ & $*$ \\
\hline $\begin{array}{ll}\text { Lines } & \\
\text { Periods }\end{array}$ & W & B & $\mathrm{Y}$ & L.S.* \\
\hline 1 st Wk & $5.03 \mathrm{a} \pm 1.04$ & $3.45 b \pm 0.543$ & $2.83 \mathrm{c} \pm 0.419$ & $*$ \\
\hline 2nd Wk & $10.98 \mathrm{a} \pm 1.57$ & $4.44 c \pm 0.736$ & $5.46 \mathrm{~b} \pm 0.536$ & $*$ \\
\hline $3 \mathrm{rd} \mathrm{Wk}$ & $12.14 \mathrm{a} \pm 1.102$ & $4.81 \mathrm{c} \pm 1.033$ & $10.60 \mathrm{~b} \pm 0.732$ & $*$ \\
\hline 4th Wk & $11.70 \mathrm{a} \pm 1.283$ & $6.75 \mathrm{c} \pm 1.195$ & $9.22 \mathrm{~b} \pm 1.246$ & $*$ \\
\hline Overall Period & $9.962 \mathrm{a} \pm 1.070$ & $4.86 \mathrm{c} \pm 0.513$ & $7.027 \mathrm{~b} \pm 0.453$ & $*$ \\
\hline$\frac{\text { Periods }}{\text { Interaction }(\mathrm{T} * \mathrm{~L})}$ & $\mathrm{T}^{0}$ & $\mathrm{~T}^{1}$ & $\mathrm{~T}^{2}$ & L.S.* \\
\hline \begin{tabular}{l|l} 
Overall & $\mathrm{W}$ \\
\cline { 2 - 2 }
\end{tabular} & $9.71 \mathrm{~b} \pm 0.041$ & $14.45 \mathrm{a} \pm 0.0273$ & $7.08 \mathrm{~d} \pm 0.018$ & $*$ \\
\hline period & $5.79 \mathrm{e} \pm 0.076$ & $6.01 . e \pm 0.0110$ & $2.80 \mathrm{f} \pm 0.036$ & $*$ \\
\hline $\mathrm{Y}$ & $7.66 \mathrm{~d} \pm 0.034$ & $5.89 \mathrm{e} \pm 0.125$ & $8.54 c \pm 0.37$ & $*$ \\
\hline L.S** & $*$ & $*$ & $*$ & \\
\hline
\end{tabular}

, b, c means in rows bearing different superscripts differ significantly at $\mathrm{P} \leq 0.05$.

** a , b , c means in column bearing different superscripts differ significantly at $\mathrm{P} \leq 0.05$.

Table (11): Effect of adding canola seed powder on red blood cells account $\left({ }^{*} 10^{\wedge} 6 / \mathrm{mm}^{3}\right)$ in different lines of local quails (Mean $+\mathrm{SE}$ ).

\begin{tabular}{|c|c|c|c|c|}
\hline \multirow{2}{*}{ Treatments (T) } & $\mathrm{T}^{0}=$ Control & $\mathrm{T}^{1}=+1 \% \mathrm{CSP}$ & $\mathrm{T}^{2}=+3 \%$ CSP & L.S.* \\
\cline { 2 - 5 } & $3.5917 \mathrm{a} \pm 0.06$ & $3.3217 \mathrm{a} \pm 0.62$ & $3.9367 \mathrm{a} \pm 0.16$ & N.S \\
\hline \multirow{2}{*}{ Lines (L) } & $\mathrm{W}$ & $\mathrm{B}$ & $\mathrm{Y}$ & L.S \\
\cline { 2 - 5 } & $3.3583 \mathrm{a} \pm 0.32$ & $3.5683 \mathrm{a} \pm 0.51$ & $3.9233 \mathrm{a} \pm 0.23$ & N.S \\
\hline Interaction $\left(\mathrm{T}^{*} \mathrm{~L}\right)$ & $\mathrm{T}^{0}$ & $\mathrm{~T}^{1}$ & $\mathrm{~T}^{2}$ & L.S \\
\hline $\mathrm{W}$ & $3.640 \mathrm{a} \pm 0.03$ & $2.630 \mathrm{a} \pm 0.76$ & $3.805 \mathrm{a} \pm 0.44$ & N.S \\
\hline $\mathrm{B}$ & $3.490 \mathrm{a} \pm 0.09$ & $3.220 \mathrm{a} \pm 1.88$ & $3.995 \mathrm{a} \pm 0.18$ & N.S \\
\hline $\mathrm{Y}$ & $3.645 \mathrm{a} \pm 0.17$ & $4.115 \mathrm{a} \pm 0.72$ & $4.010 \mathrm{a} \pm 0.35$ & N.S \\
\hline L.S** & $\mathrm{N} . S$ & $\mathrm{~N} . S$ & N.S & \\
\hline
\end{tabular}


Table (12): Effect of adding canola seed powder on hemoglobin (g/dl) in different lines of local quails (Mean $+\mathrm{SE})$.

\begin{tabular}{|c|c|c|c|c|}
\hline \multirow[t]{2}{*}{ Treatments $(\mathrm{T})$} & $\mathrm{T}^{0}=$ Control & $\mathrm{T}^{1}=+1 \% \mathrm{CSP}$ & $\begin{array}{c}\mathrm{T}^{2}=+3 \% \\
\mathrm{CSP}\end{array}$ & L.S.* \\
\hline & $17.083 \mathrm{a} \pm 0.31$ & $18.300 \mathrm{a} \pm 1.61$ & $18.433 \mathrm{a} \pm 0.83$ & N.S \\
\hline \multirow[t]{2}{*}{ Lines (L) } & $\mathrm{W}$ & $\mathrm{B}$ & $\mathrm{Y}$ & L.S* \\
\hline & $17.417 \mathrm{a} \pm 0.65$ & $18.867 \mathrm{a} \pm 1.29$ & $17.533 \mathrm{a} \pm 1.12$ & N.S \\
\hline Interaction $\left(\mathrm{T}^{*} \mathrm{~L}\right)$ & $\mathrm{T}^{0}$ & $\mathrm{~T}^{1}$ & $\mathrm{~T}^{2}$ & L.S* \\
\hline $\mathrm{W}$ & $17.250 \mathrm{a} \pm 0.05$ & $15.850 \pm 0.55$ & $19.150 \mathrm{a} \pm 0.75$ & N.S \\
\hline $\mathrm{B}$ & $17.700 \mathrm{a} \pm 0.60$ & $20.250 \mathrm{a} \pm 4.55$ & $18.650 \mathrm{a} \pm 0.75$ & N.S \\
\hline $\mathrm{Y}$ & $16.300 \mathrm{a} \pm 0.20$ & $18.800 \mathrm{a} \pm 2.80$ & $17.500 \mathrm{a} \pm 2.80$ & N.S \\
\hline L.S** & N.S & N.S & N.S & \\
\hline
\end{tabular}

Table (13): Effect of adding canola seed powder on hematocrit (\%) in different lines of local quails (Mean $+\mathrm{SE})$.

\begin{tabular}{|c|c|c|c|c|}
\hline \multirow{2}{*}{ Treatments (T) } & $\mathrm{T}^{0}=$ Control & $\mathrm{T}^{1}=+1 \%$ CSP & $\mathrm{T}^{2}=+3 \%$ CSP & L.S.* \\
\cline { 2 - 5 } & $27.967 \mathrm{~b} \pm 0.72$ & $26.300 \mathrm{~b} \pm 3.41$ & $50.517 \mathrm{a} \pm 5.86$ & $*$ \\
\hline \multirow{2}{*}{ Lines (L) } & $\mathrm{W}$ & $\mathrm{B}$ & $\mathrm{Y}$ & L.S* \\
\cline { 2 - 5 } & $31.917 \mathrm{a} \pm 5.22$ & $37.500 \mathrm{a} \pm 6.73$ & $35.367 \mathrm{a} \pm 6.62$ & N.S \\
\hline Interaction ( T*L) & $\mathrm{T}^{0}$ & $\mathrm{~T}^{1}$ & $\mathrm{~T}^{2}$ & L.S* \\
\hline $\mathrm{W}$ & $28.95 \mathrm{~b} \pm 0.05$ & $27.05 \mathrm{~b} \pm 0.75$ & $39.75 \mathrm{ab} \pm 17.75$ & N.S \\
\hline $\mathrm{B}$ & $29.25 \mathrm{~b} \pm 0.15$ & $27.30 \mathrm{~b} \pm 12.90$ & $55.95 \mathrm{a} \pm 1.15$ & $*$ \\
\hline $\mathrm{Y}$ & $25.70 \mathrm{~b} \pm 0.10$ & $24.55 \mathrm{~b} \pm 1.75$ & $55.85 \mathrm{a} \pm 4.95$ & $*$ \\
\hline L.S $* *$ & $\mathrm{~N} . S$ & $\mathrm{~N} . S$ & $\mathrm{~N} . S$ & \\
\hline
\end{tabular}

\section{CONCLUSIONS}

Using RAPD - PCR marker for a genetic relationship, noted that genetic variations refer to the good genetic resources in the local quail. On the other hand inclusion of natural ingredients in the feed of local quail such as canola seed, can improve body weight, feed conversion, Egg weight and mass. Egg production. Besides, it can improve metabolic energy in laying birds that stimulate bone marrow to produce more red blood cells to provide more oxygen due to erythrocytes number is a signal of the oxygen transfer capacity in the blood thus it can be used as an indicator of health in birds since its contribution in improving the body defense system against diseases. 
الأداء الإنتاجي، وبعض الصفات الاموية والعلاقة الجينية في الخطوط المختلفة من السمان المحلي المتأثر بإستخدام مستويات مختلفة من مسحوق بذور اللفت (كانولا)

حورية صابر عبدالرزاق شيرين ظاهرحمد جنان نجدت عبدالرحمان سردار ياسين سرداري قسم الانتاج الحيوانى, كلية علوم الهندسة الزراعية - جامعة صلاح الدين - العراق

Email: Hurea.Abdulrazaq@su.edu.krd

\section{الخلاصة}

أجريت هذه الدراسة لمعرفة تأثير مستوين من مسحوق بذور الكانولا في خطوط السمان المختلفة وتأثير التداخل مـابين الخطوط الوراثية ومستويات مسـخوق بـذور الكانولا على الأداء الإنتاجي وبعض الصـفات الدمويـة والعلاقـة الوراثيـة. تم تربيـة 162 طير من السمان في ثلاثتة خطوط اللون الأبيض والأسود والبني الصفراء. وزعت الطيور بشكل عشوائي على ثلاث مجموعات تجريبية مع ثلاث مكررات وثلاث خطوط.

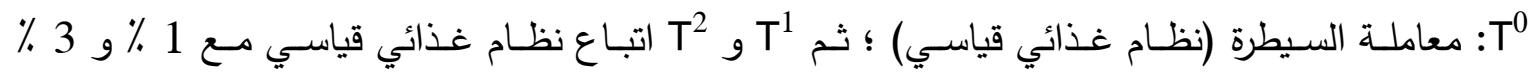
مسحوق بذور الكانولا (CSP) على التوالي. أثارت نتائج العلاقة الوراثية باستخدام RAPD - PCR إلى أن قيم التشابه الوراثي تتراوح بين 0.5 إلى 1. كان أكبر عدد من الحزم 28 بين جميع المجموعات المستخدمة. 200pb) أعلى نسبة من تعدد الأشكال لوحظ في البادء OPA-14. أعلى مجموعة من الوزن الجزيئي كانت

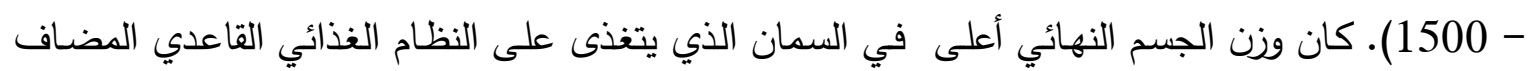
إلى 3 ٪ من (CSP). كانت الاختلافات بين مجموعات الخطوط كبيرة (PS0.05) اذ أظهر الخط البني

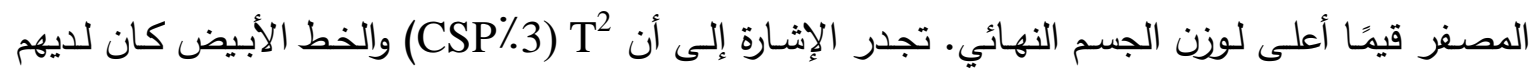

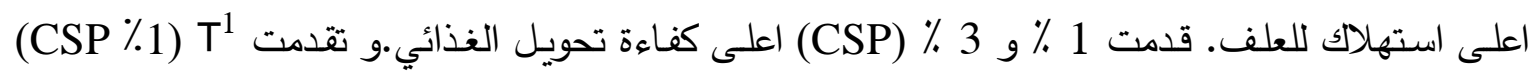
في ارتفاع وزن البيض ، وكتلة البيض وإنتاج بيض. في حين سجلت T2 أعلى المستويات الهيماتوكريت. بثكل عام ، يمكن الاستتاج والتوصية بأن استخدام 1 \% ، 3 \% (CSP) يساعد على تحسين عملية التمثيل الغذائي في الجسم ويحسن الأداء والصحة في خطوط السمان المحلية المختلفة.

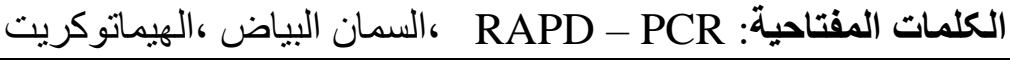

$$
\text { تاريخ تسلم البحث: 2020/2/29 ، وقبوله: 2020/4/25 }
$$

\section{REFERENCES}

Abdulrazaq, H.S. and Suliaman, N.M.A., (2016). Genetic relationship and similarity of some chicken strains. ZANCO Journal of Pure and Applied Sciences, 28(5), pp.78-83.

Ali, B.A. and Ahmed, M.M.M., (2001). Random amplified polymorphic DNA in some chicken strains. In Proceeding of the Congress of Role of Biochemistry in Environment and Agriculture. Part I (pp. 23-31).

Ali, B.A., Ahmed, M.M.M. and Aly, O.M., (2003). Relationship between genetic similarity and some productive traits in local chicken strains. African Journal of Biotechnology, 2(2), pp.46-47. 
Ali, B.A., Ahmed, M.M.M., El-Deen, M.B. and Shalan, H.M., (2002). Genetic variability in the 17th generation of Japanese quail selected for high eggs and meat production. Egypt. Poult. Sci. J, 22, pp.59-71.

Bawej, M., Kokoszyński, D. and Bernacki, Z., (2012). Evaluation of genetic similarity between white and grey varieties of Guinea fowl (Numida meleagris). Journal of Central European Agriculture, 13(4), pp.0-0.

Bowditch, B.M., Albright, D.G., Williams, J.G. and Braun, M.J., (1993). Use of randomly amplified polymorphic DNA markers in comparative genome studies. In Methods in enzymology (Vol. 224, pp. 294-309). Academic Press.

Chen, W., Jiang, Y.Y., Wang, J.P., Huang, Y.Q. and Wang, Z.X., (2014). Effects of dietary flaxseed meal on production performance, egg quality, and hatchability of Huoyan geese and fatty acids profile in egg yolk and thigh meat from their offspring. Livestock Science, 164, pp.102-108.

Costa, F.G.P., Souza, J.G.D., Silva, J.H.V.D., Rabello, C.B.V., Goulart, C.D.C., Neto, L. and da Cunha, R., (2008). Influência do óleo de linhaça sobre o desempenho e a qualidade dos ovos de poedeiras semipesadas. Revista Brasileira de Zootecnia, 37(5), pp.861-868.

Duncan, D.B., (1955). Multiple range and multiple F tests. Biometrics, 11(1), pp.142.

Emenalom, O.O., Okoli, I.C. and Udedibie, A.B.I., (2004). Observations on the pathophysiology of weaner pigs fed raw and preheated Nigerian Mucuna pruriens (velvet bean) seeds. Pakistan Journal of Nutrition, 3(2), pp.112117.

Hameed, S.A.J.I.D., Ahmad, N.I.S.A.R. and Rabbani, M., (2002). Effect of replacing dietary levels of soybean meal with canola meal in Japanese quail. International Journal of Agriculture and Biology, 4(3), pp.389-391.

Harker, K.N., O’Donovan, J.T., Smith, E.G., Johnson, E.N., Peng, G., Willenborg, C.J., Gulden, R.H., Mohr, R., Gill, K.S. and Grenkow, L.A., (2015). Seed size and seeding rate effects on canola emergence, development, yield and seed weight. Canadian Journal of Plant Science, 95(1), pp.1-8.

Howard, R. and Moore, A., (1991). A complete checklist of the birds of the world (No. Ed. 2). Academic Press Ltd.

Khosravi, H., Mehri, M., Bagherzadeh-Kasmani, F. and Asghari-Moghadam, M., (2016). Methionine requirement of growing Japanese quails. Animal Feed Science and Technology, 212, pp.122-128.

Kocevski, D., Nikolova, N. and Kuzelov, A., (2011). The influence of strain and age on some egg quality parameters of commercial laying hens.

Levin, I., Crittenden, L.B. and Dodgson, J.B., (1993). Genetic map of the chicken Z chromosome using random amplified polymorphic DNA (RAPD) markers. Genomics, 16(1), pp.224-230.

Li, L., Zhang, J., Zhu, J.Q., Gu, S., Sun, Q., Zhou, G.M., Fu, C.X., Li, Q., Chen, L.Y., Li, D.X. and Liu, S.J., (2006). Genetic diversity of nine populations of the black goat (Capra hircus) in Sichuan, PR China. Zoological science, 23(3), pp.229-234. 
Mailer, R.J., McFadden, A., Ayton, J. and Redden, B., (2008). Anti-nutritional components, fibre, sinapine and glucosinolate content, in Australian canola (Brassica napus L.) meal. Journal of the American Oil Chemists' Society, 85(10), pp.937-944.

Minias, P., (2015). The use of haemoglobin concentrations to assess physiological condition in birds: a review. Conservation physiology, 3(1), p.cov007.

Mnisi, C.M. and Mlambo, V., (2018). Growth performance, haematology, serum biochemistry and meat quality characteristics of Japanese quail (Coturnix coturnix japonica) fed canola meal-based diets. Animal Nutrition, 4(1), pp.37-43.

Mnisi, C.M., Mlambo, V., Phatudi, K.G.G. and Matshogo, T.B., (2017). Exogenous carbohydrases do not improve the physiological and meat quality parameters of female Japanese quail fed canola-based diets. South African Journal of Animal Science, 47(6), pp.923-932.

Moraes, P.D.O., Gopinger, E., Bavaresco, C., Catalan, A.A.D.S., Dias, R.C. and Xavier, E.G., (2017). Productive performance, egg quality and bone characteristics of quails fed with meal and canola oil. Acta Scientiarum. Animal Sciences, 39(1), pp.97-102.

Moraes, P.D.O., Gopinger, E., Catalan, A.A., Castro, M.L.S.D., Elias, M.C. and Xavier, E.G., (2015). Effect of feeding canola meal to laying Japanese quails. Acta Scientiarum. Animal Sciences, 37(3), pp.295-299.

Moraes, P.D.O., Gopinger, E., Catalan, A.A., Castro, M.L.S.D., Elias, M.C. and Xavier, E.G., (2015). Effect of feeding canola meal to laying Japanese quails. Acta Scientiarum. Animal Sciences, 37(3), pp.295-299.

Nahashon, S.N., Adefope, N., Amenyenu, A., Wright, D., Payne, L., (2003). Nutritional and genetic approaches for improving guinea fowl production efficiency. Cooperative Agricultural Research Program Seminar Series, Tennessee State University.

Pantaya, D. and Utami, M.M.D., (2018), November. The blood haematological profile on laying hens that treated by different levels of yeast supplementation. In IOP Conference Series: Earth and Environmental Science (Vol. 207, No. 1, p. 012033). IOP Publishing.

Ravindran, V., Hew, L.I., Ravindran, G. and Bryden, W.L., (2005). Apparent ileal digestibility of amino acids in dietary ingredients for broiler chickens. Animal Science, 81(1), pp.85-97.

SAS, (2012). Statistical analysis system. SAS / STAT User's Guide, Version 9.1. SAS. Inst. Inc., Cary, NC.

Sergent, N., Rogers, T. and Cunningham, M., (2004). Influence of biological and ecological factors on hematological values in wild Little Penguins, Eudyptula minor. Comparative Biochemistry and Physiology Part A: Molecular \& Integrative Physiology, 138(3), pp.333-339.

Sharma, D. and Dhama, K., (2007). Genetic polymorphism between guinea fowl lines with high and low antibody response to sheep red blood cells using randomly amplified polymorphic DNA (RAPD) markers. Indian Journal 
of Comparative Microbiology, Immunology and Infectious Diseases, 28(1and2), pp.45-47.

Sharma, D., Appa Rao, K.B.C., Singh, R.V. and Totey, S.M., (2001). Genetic diversity among chicken breeds estimated through randomly amplified polymorphic DNA. Animal Biotechnology, 12(2), pp.111-120.

Sharma, D., Rao, K.A. and Totey, S.M., (2000). Measurement of within and between population genetic variability in quails. British poultry science,41(1), pp.29-32.

Singh, R.V. and Sharma, D., (2002). Within-and between-strain genetic variability in White Leghorn detected through RAPD markers. British poultry science, 43(1), pp.33-37.

Song, G., Sharma, A.D., Roll, G.R., Ng, R., Lee, A.Y., Blelloch, R.H., Frandsen, N.M. and Willenbring, H., (2010). MicroRNAs control hepatocyte proliferation during liver regeneration. Hepatology, 51(5), pp.1735-1743.

Sultana, A., Smith, C.T., Cunningham, D., Starling, N., Neoptolemos, J.P. and Ghaneh, P., (2007). Meta-analyses of chemotherapy for locally advanced and metastatic pancreatic cancer. Journal of Clinical Oncology, 25(18), pp.2607-2615.

Vargas-Sánchez, R.D., Ibarra-Arias, F.J., del Mar Torres-Martínez, B., SánchezEscalante, A. and Torrescano-Urrutia, G.R., (2019). Use of natural ingredients in Japanese quail diet and their effect on carcass and meat quality-A review. Asian-Australasian journal of animal sciences, 32(11), p.1641.

Veras, A.G., Souza, J.G.D., Teixeira, E.N.M., Moreira, J.A., Marinho, A.L., Diógenes, G.V., Ferreira, L.H.G. and Chemane, I.A., (2019). Canola and coconut oils in the feed of European quails (Coturnix coturnix). Revista Brasileira de Zootecnia, 48.

Zhang, J., Li, L., Zhu, J.Q., Gu, S., Sun, Q., Zhou, G.M., Fu, C.X., Li, Q., Chen, L.Y., Li, D.X. and Liu, S.J., (2006). Genetic diversity of nine populations of the black goat (Capra hircus) in Sichuan, PR China. Zoological science, 23(3), pp.229-234. 